\title{
Original Article (short paper) \\ Chilean sport sciences scientific production indexed in the Web of Science (1981-2016)
}

\author{
Mikel Pérez-Gutiérrez ${ }^{1 *}$, Carlos Cobo-Corrales ${ }^{1}$, Eugenio Izquierdo-Macón ${ }^{2}$ \\ ${ }^{1}$ Department of Education. Universidad de Cantabria, Spain; ${ }^{2}$ Department of Physical Education and Sports. Universidad de León, Spain.
}

\begin{abstract}
Aim: To carry out a bibliometric analysis of the Chilean Sport Sciences scientific production indexed in the Web of Science until 2016. Methods: Chilean Sport Sciences articles and reviews included in the Web of Science Core Collection indexes until 2016 were analyzed. Data was collected and filtered in Endnote X6 programme and then exported to Excel 2013, Bibexcel and Histcite for analysis. Bibliometrics was focused on productivity, subjects and collaboration patterns. Results: A total of 152 documents published from 1981 to 2016 were found. Life Sciences was the main research area (104), while Physiology (36) and Sports Training Theory (30) were the most represented subjects. The mean of authors per article was 5.26 and the percentage of collaboration was mainly between $94 \%$ and $100 \%$. Ramirez-Campillo was the most prolific author (24) and Caniuqueo achieved the highest collaboration index (10.83). Two networks, with 20 and 10 scholars respectively and representing 19 different institutions, were discovered. A cluster of 53 different journals has disseminated Chilean Sport Sciences publications, but 12 of them collected $60.53 \%$ of total production. Conclusion: Chilean Sport Sciences scientific production indexed in the Web of Science shows the progressive development and strengthening of this field of knowledge, clearly oriented to Life Sciences, teamwork and international collaboration. The establishment of a network including scholars from Australia, Brazil, Canada, Chile and Spain, which is propelling Sport Sciences research in this country, should be also highlighted.
\end{abstract}

Keyword: bibliometrics, collaboration, scientific production, chile, sport sciences

\section{Introduction}

The development of science in Chile was officially strengthened in 1967 with the establishment of the Comision Nacional de Investigación Científica y Tecnológica [National Commission for Scientific and Technological Research] and its promotion and support of science and technology for contributing to the economic, social and cultural development of the country ${ }^{1}$. In 1982 the Fondo Nacional de Desarrollo Cientifico y Tecnológico [National Fund for Scientific and Technological Development] was also created for funding individual research, supporting more than 16.000 projects until present day ${ }^{2}$.

On the other hand, the constant, progressive and exponential rise of research information worldwide ${ }^{3,4}$ has caused the appearance of new techniques for analyzing this information. Bibliometrics has proven to be "the main tool of science, quantitative analysis" ${ }^{5}$ and it is a growing field whose procedures have been applied to Chilean scientific output ${ }^{6}$. Thus, the last report indicated Chile had grown an average of $8.2 \%$ every year during the period 2009-2013 while in the rest of world was at $2.4 \%$. In 2013, 9.178 documents were published and the amount of researchers rose to $5.943^{6}$. This report also stated a $49.93 \%$ of international collaboration, being the United States of America, Spain, Germany, France and England the most collaborative countries. Regarding research area, Social Sciences and Arts and Humanities presented a significant rise of researchers from 2003 to 2012 due to the increase of international collaborators.

Regarding the development of Sport Sciences in Chile, its history dates back to 1906 with the establishment of the Instituto de Educación Física y Manual [Physical Education and Manual Institute] at the University of Chile ${ }^{7-10}$. From that time onwards, the spread of Sport Sciences field of knowledge is represented by the progressive growth of institutions and universities ${ }^{11,12}$, academics and scholars ${ }^{13}$ and consequently, the amount of courses and programmes ${ }^{11,14}$, journals ${ }^{15}$ as well as research output ${ }^{13,16}$, influenced by the different social, economic, political and cultural events happened ${ }^{16-19}$. For instance, there are currently more than 30 universities, some of them with several campuses along the country and evening programmess, offering Sport Sciences-related degrees in Chile ${ }^{14,20}$, nine Master and one Doctoral programmes ${ }^{21}$.

From a bibliometric approach, several works have been developed in Chile in Sport Sciences field. These works have offered a comparison of the Sports Sciences scientific development of Chile within its South American context ${ }^{13}$, the history and contribution of its journals ${ }^{10,15,22}$ as well as its evolution along time in Chile ${ }^{16,23}$. Nevertheless, the contribution of Chilean scholars to the development of Sport Sciences at the international level has not been studied yet. Thus, the aim of the present study was to carry out a bibliometric analysis focused on productivity, subjects and collaboration patterns of the Chilean Sport Sciences scientific production indexed in the Web of Science until 2016. This analysis could complement previous works, provide academics an international overview of this field along history and allow a national-international data comparison.

\section{Method}

Chilean Sport Sciences articles and reviews included in the Web of Science Core Collection indexes such as Science Citation Index Expanded (SCI-EXPANDED), Social Sciences Citation Index (SSCI) as well as Arts \& Humanities Citation Index (A\&HCI) and published from 1900 to 2016 were included in the present 
study. Those works classified as articles and reviews by the Web of Science were selected as the current main documents for the dissemination of knowledge. Web of Science indexes and time span were set following the methodology proposed by Andrade, López, Ramírez-Campillo, Beltrán, Rodríguez $z^{13}$ and the recommendations offered by Thomson Reuters ${ }^{24}$, respectively.

Then, a search string was created for data mining including Chile as the country of affiliation of authors as well as Web of Science categories related with Sport Sciences. These were Hospitality, Leisure, Sport \& Tourism; Psychology, Applied; Sport Sciences; Education \& Educational Research; and Education, Special. These categories were selected due to the multidisciplinary approach of Sport Sciences ${ }^{25}$. In this way, search string was the following:

$\mathrm{CU}=$ Chile AND $\mathrm{WC}=($ Hospitality, Leisure, Sport \& Tourism OR Psychology, Applied OR Sport Sciences OR Education \& Educational Research OR Education, Special)

It should be highlighted Chilean Sport Sciences scientific production does not represent the scientific output of Chilean academics and/or scholars since foreign authors are also working in Chilean universities and/or institutions. The advanced search tool included in the Web of Science presents the affiliation of authors but not their nationality. Moreover, authors affiliated to non-Chilean institutions are also included in the present study because they have collaborated and signed papers with authors working in Chilean organizations.

Results were then filtered by document type for including only articles and reviews. Full record of results was exported to the Endnote X6 reference manager and title, abstract and keywords were checked for considering article's final inclusion regarding its topic.

Obtained results were classified according to their subject and research area, following the criteria used by Devís-Devís, Valenciano Valcárcel, Villamón, Pérez-Samaniego ${ }^{25}$ and the Web of Science ${ }^{26}$ respectively, and then exported to Excel 2013 for developing the bibliometric analysis focused on productivity ${ }^{27}$.
The analysis included the following variables: distribution of articles per year, subject and research area, single-authored articles (SA), multi-authored articles (MA), mean of authors per article and percentage of collaboration. Percentage of collaboration $(\% \mathrm{C})$ was calculated following the methodology used by Valenciano Valcárcel, Devís-Devís, Villamón, Peiró-Velert ${ }^{28}$, being: $\% \mathrm{C}=\mathrm{MA} / \mathrm{SA}+\mathrm{MA}$. Moreover, number of articles, signatures, collaborators and collaboration index were also calculated for those authors with six or more articles.

Then, Bibexcel and Histcite were selected for analysing the source journals and preparing the co-authorship network within Chilean Sport Sciences scientific production, following the methodology used by similar works ${ }^{29,30}$. Thus, number of published documents, number of citations in the collection to the journal (Total Local Citation Score; TLCS), total citations in the Web of Science to papers in the journal in the collection (Total Global Citation Score; TGCS) and co-authorship structure was determined. Finally, the map of collaboration for clusters of researchers with more than three members was depicted using Pajek software.

\section{Results}

A total of 152 documents (145 articles and 7 reviews) were found. They were published between 1981 and 2016, first irregularly and constantly from 2008 onwards and appearing a significant rise from 2013 onwards $(260 \%$ in relation to the amount of documents published in 2012). Documents have been classified in 3 different research areas and 15 subjects as shown in Table 1 . Life Sciences was the main research area, collecting 104 documents, while Physiology and Sports Training Theory were the most important subject with 36 and 30 documents respectively. Within Social Sciences, the second most represented research area (42 documents), Psychology and Sociology achieved the highest figures with 14 and 12 documents respectively. On the other hand, some subjects such as Documentation or Management were only represented in one document.

Table 1- Frequency distribution of published articles by year of publication, research area and subject.

\begin{tabular}{|c|c|c|c|c|c|c|c|c|c|c|c|c|c|c|}
\hline Research area \& subject & $\begin{array}{l}\overrightarrow{0} \\
\stackrel{\infty}{-}\end{array}$ & 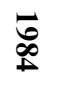 & : & 气ั气̆ & ڤ్ڤ & 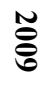 & $\stackrel{\widetilde{O}}{0}$ & $\tilde{气}$ & $\stackrel{\widetilde{N}}{\stackrel{N}{N}}$ & $\stackrel{\widetilde{\omega}}{\omega}$ & $\stackrel{\widetilde{O}}{\Phi}$ & $\stackrel{\widetilde{E}}{u}$ & $\stackrel{\widetilde{O}}{\sigma}$ & Total \\
\hline Life Sciences & 1 & 1 & 1 & 1 & $\mathbf{0}$ & 2 & 1 & 4 & 3 & 12 & 23 & 25 & 30 & 104 \\
\hline Biomechanics & & 1 & & & & & & & & & 1 & 3 & 8 & 13 \\
\hline Kinesiology & & & & & & & & & & 1 & 2 & 1 & 1 & 5 \\
\hline Nutrition & & & & & & & & & & & 3 & & 2 & 5 \\
\hline Physiology & 1 & & 1 & 1 & & 2 & & & 2 & 6 & 8 & 7 & 8 & 36 \\
\hline Sports Medicine & & & & & & & 1 & 2 & & & 3 & 4 & 5 & 15 \\
\hline Sports Training Theory & & & & & & & & 2 & 1 & 5 & 6 & 10 & 6 & 30 \\
\hline Social Sciences & $\mathbf{0}$ & $\mathbf{0}$ & $\mathbf{0}$ & $\mathbf{0}$ & 1 & 1 & 1 & 1 & 2 & 5 & 12 & 8 & 11 & 42 \\
\hline Didactics & & & & & & & & & & 2 & & 1 & & 3 \\
\hline Economics & & & & & & 1 & & & & & 1 & & & 2 \\
\hline
\end{tabular}




\begin{tabular}{|c|c|c|c|c|c|c|c|c|c|c|c|c|c|c|}
\hline Mathematical Methods & & & & & & & & & & & & 2 & 1 & 3 \\
\hline PE\&ST & & & & & & & & & 1 & & 3 & 2 & 2 & 8 \\
\hline Psychology & & & & & 1 & & 1 & & 1 & 3 & 3 & & 5 & 14 \\
\hline Sociology & & & & & & & & 1 & & & 5 & 3 & 3 & 12 \\
\hline Technology & $\mathbf{0}$ & $\mathbf{0}$ & $\mathbf{0}$ & $\mathbf{0}$ & $\mathbf{0}$ & $\mathbf{0}$ & $\mathbf{0}$ & $\mathbf{0}$ & $\mathbf{0}$ & 1 & $\mathbf{0}$ & 3 & 2 & 6 \\
\hline Documentation & & & & & & & & & & & & & 1 & 1 \\
\hline Management & & & & & & & & & & & & 1 & & 1 \\
\hline Scientometrics & & & & & & & & & & 1 & & 2 & 1 & 4 \\
\hline Total & 1 & 1 & 1 & 1 & 1 & 3 & 2 & 5 & 5 & 18 & 35 & 36 & 43 & 152 \\
\hline
\end{tabular}

PE \& ST: Physical Education and Sports Theory.

Source: prepared by authors.

The first published article in each subject is shown in Table 2, depicting two different periods for the inclusion of Chilean Sport Sciences scientific subjects within the Web of Science.
While the first published physiological and biomechanical articles were indexed during the 1980s, the rest of subjects have appeared from 2008 onwards.

Table 2- Reference of the first published article in each subject.

\begin{tabular}{c} 
Reference \\
\hline $\begin{array}{l}\text { Quintana G, Puig A, Huberman J, Holzts H, Donoso H. Application and methodological analysis of measuring } \\
\text { anaerobic capacity (Wingate test) in various sports specialities. Int J Sports Med. } 1981 ; 2(4): 265-6 .\end{array}$ \\
Brandan ME, Gutierrez M, Labbe R, Menchacarocha A. Measurement of the terminal velocity in air of a ping-pong \\
ball using a time-to-amplitude converter in the millisecond range. Am J Phys. 1984; 52(10):890-3. \\
Tobar BU. Psychological intervention for detecting and managing attributional styles in two motorized sports: rally \\
and competitive karting. Rev Psicol Deporte. 2008; 17(2):205-19. \\
Chumacero RA. Altitude or Hot Air? J Sport Econ. 2009; 10(6):619-38.
\end{tabular}

Guzman MEG, Cerda MAC, Castro LME, Astorga TCD. Sports activities in first year high school students in Osorno (Chile). Rev Int Med Cienc Act Fis Dep. 2011; 11(41):145-63.

Sociology

Gonzalez G, Oyarzo C, Fischer M, De la Fuente MJ, Diaz V, Berral FJ. Specific training of the postural balance in the young soccer players. Rev Int Med Cienc Act Fis Dep. 2011; 11(41):95-114.

Sports Training Theory

Dona AM, Cervantes CT, Garcia ER. The role of Physical Education in schools in 21st century. the university professor's view. Movimento. 2012; 18(4):33-54.

PE\&ST

Mauricio CO, Rungue MS, Larraguibel R, Ortega DR. Inter-sesion confidence of balance assessment with TOBtrainer $^{\mathrm{MR}}$. Rev Bras Med Esporte. 2013; 19(5):376-8.

Kinesiology

Toro-Arevalo S, Oliva I, Tapia JQ. Development of a device for observation of Physical Education classes at elementary school level: a naturalist perspective from teaching experience. Movimento. 2013; 19(1):161-81.

Andrade DC, Lopez BA, Ramirez-Campillo R, Beltran AR, Rodriguez RP. Bibliometric analysis of South American
research in sports science from 1970 to 2012. Motriz: J. Phys. Ed. 2013; 19(4):783-91.

Andrade DC, Lopez BA, Ramirez-Campillo R, Beltran AR, Rodriguez RP. Bibliometric analysis of S
research in sports science from 1970 to 2012. Motriz: J. Phys. Ed. 2013; 19(4):783-91.

Didactics

Scientometrics

Cox GR, Mujika I, van den Hoogenband CR. Nutritional Recommendations for Water Polo. Int J Sport Nutr Exerc Metab. 2014; 24(4):382-91.

Nutrition

Garcia-Rubio J, Gomez MA, Lago-Penas C, Ibanez SJ. Effect of match venue, scoring first and quality of opposition on match outcome in the UEFA Champions League. Int J Perform Anal Sport. 2015; 15(2):527-39.

Mathematical Methods

Sanchez-Martin M, Chacon-Moscoso S, Sanduvete-Chaves S. Enhancing quality in training programs: an application in the sport area. Rev Int Med Cienc Act Fis Dep. 2015; 15(60):613-29.

Management

Lebeau JC, Liu SC, Saenz-Moncaleano C, Sanduvete-Chaves S, Chacon-Moscoso S, Becker BJ, et al. Quiet Eye and Performance in Sport: A Meta-Analysis. J Sport Exerc Psychol. 2016; 38(5):441-57.

Documentation

PE \& ST: Physical Education and Sports Theory.

Source: prepared by authors. 
Regarding the collaboration patterns, Table 3 shows the predominance of multi-authored articles. The mean of authors per article was 5.26, ranging from one to 10 . The percentage of collaboration was between $94 \%$ and $100 \%$ with the exception of 2008, when a single-authored article was only published, and 2009 , with a $66.67 \%$ of collaboration.

Table 3- Distribution of the amount of single-authored articles, multi-authored articles, mean of authors per article and percentage of collaboration per year.

\begin{tabular}{|c|c|c|c|c|}
\hline Year & Single authored papers & Multi-authored papers & Mean authors/paper & $\%$ of collaboration \\
\hline 1981 & 0 & 1 & 5 & 100 \\
\hline 1984 & 0 & 1 & 4 & 100 \\
\hline 1999 & 0 & 1 & 10 & 100 \\
\hline 2005 & 0 & 1 & 7 & 100 \\
\hline 2008 & 1 & 0 & 1 & 0 \\
\hline 2009 & 1 & 2 & 6 & 66.67 \\
\hline 2010 & 0 & 2 & 4.5 & 100 \\
\hline 2011 & 0 & 5 & 5.4 & 100 \\
\hline 2012 & 0 & 5 & 5.4 & 100 \\
\hline 2013 & 0 & 18 & 4.33 & 100 \\
\hline 2014 & 2 & 33 & 4.43 & 94.29 \\
\hline 2015 & 1 & 35 & 5.42 & 97.22 \\
\hline 2016 & 1 & 42 & 5.91 & 97.67 \\
\hline Total & 6 & 146 & 5.26 & 96.05 \\
\hline
\end{tabular}

Source: prepared by authors

A group of 15 authors has published six or more documents, being Ramirez-Campillo the most prolific with 24 articles, followed by Izquierdo with 15 publications. The collaboration index fluctuated from 4.83 to 10.83; achieving Caniuqueo the highest score (Table 4). On the other hand, the most productive authors have collaborated at least with 23 scholars, representing the extent of the collaboration network surrounding the Chilean Sport
Sciences publications included in the Web of Science. RamirezCampillo was the most collaborative author, working with 166 scholars. Moreover, six foreign scholars from Brazil (Nakamura and Loturco) and Spain (Izquierdo, Mujika, Colado and Flandez) are included within this group of most productive authors, depicting they are working closely together with scholars affiliated to Chilean institutions for developing research in this field.

Table 4- List of most productive authors ( $\geq 6$ papers), with institutional affiliations and collaboration patterns.

\begin{tabular}{|c|c|c|c|c|c|}
\hline Author & Papers & Signatures & Collaboration Index & Collaborators & Institutional affiliation \\
\hline R. Ramirez-Campillo & 24 & 190 & 7.92 & 166 & $\begin{array}{c}\text { Universidad de Los Lagos, } \\
\text { Osorno, Chile }\end{array}$ \\
\hline M. Izquierdo & 15 & 136 & 9.07 & 121 & $\begin{array}{l}\text { Universidad Pública de } \\
\text { Navarra, Tudela, Spain }\end{array}$ \\
\hline C. Martinez-Salazar & 13 & 126 & 9.69 & 113 & $\begin{array}{c}\text { Universidad de La Frontera, } \\
\text { Temuco, Chile }\end{array}$ \\
\hline C. Henriquez-Olguin & 12 & 99 & 8.25 & 87 & $\begin{array}{l}\text { Universidad de Chile, } \\
\text { Santiago, Chile }\end{array}$ \\
\hline D. C. Andrade & 12 & 95 & 7.92 & 83 & $\begin{array}{l}\text { Universidad de Antofagasta, } \\
\text { Antofagasta, Chile }\end{array}$ \\
\hline I. Mujika & 12 & 43 & 3.58 & 31 & $\begin{array}{l}\text { University of the Basque } \\
\text { Country, Leioa, Spain }\end{array}$ \\
\hline
\end{tabular}




\begin{tabular}{|c|c|c|c|c|c|}
\hline C. Alvarez-Lepin & 11 & 94 & 8.55 & 83 & $\begin{array}{l}\text { Family Health Centre Los } \\
\text { Lagos, Los Lagos, Chile }\end{array}$ \\
\hline L. Penailillo & 10 & 55 & 5.50 & 45 & $\begin{array}{l}\text { Universidad Finis Terrae, } \\
\text { Santiago, Chile }\end{array}$ \\
\hline F. Y. Nakamura & 9 & 80 & 8.89 & 71 & $\begin{array}{l}\text { Universidade Estadual } \\
\text { Londrina, Londrina, Brazil }\end{array}$ \\
\hline J. C. Colado & 7 & 43 & 6.14 & 36 & $\begin{array}{l}\text { Universidad de Valencia, } \\
\text { Valencia, Spain }\end{array}$ \\
\hline J. Flandez & 7 & 43 & 6.14 & 36 & $\begin{array}{l}\text { Universidad de Valencia, } \\
\text { Valencia, Spain }\end{array}$ \\
\hline A. Caniuqueo & 6 & 65 & 10.83 & 59 & $\begin{array}{l}\text { Universidad Autónoma de } \\
\text { Chile, Temuco, Chile }\end{array}$ \\
\hline H. Zbinden-Foncea & 6 & 29 & 4.83 & 23 & $\begin{array}{l}\text { Universidad Finis Terrae, } \\
\text { Santiago, Chile }\end{array}$ \\
\hline I. Loturco & 6 & 48 & 8.00 & 42 & $\begin{array}{c}\text { NAR Nucleus High } \\
\text { Performance Sport, Sao Paulo, } \\
\text { Brazil }\end{array}$ \\
\hline M. Castro-Sepulveda & 6 & 43 & 7.17 & 37 & $\begin{array}{l}\text { Universidad Finis Terrae, } \\
\text { Santiago, Chile }\end{array}$ \\
\hline
\end{tabular}

Source: prepared by authors

Regarding the map of the collaboration patterns, two networks were discovered with 20 and 10 scholars respectively and representing 19 different institutions (Figure 1). The first network almost collects as many institutions as authors. There is a strong relationship between most of them, although some scholars such as Mujika, Pereira or Zbinden-Foncea collaborate to a lesser extent. Moreover, this network shows the international collaboration of Chilean institutions with countries such as Australia, Brazil, Canada or Spain. The second network presents two clusters of scholars collaborating, being Colado and Flandez the most productive authors, and four different institutions from Chile and Spain are working together.

Figure 1 - Author clusters ( $>3$ members) when a threshold of $\geq 3$ co-authored publications is applied.
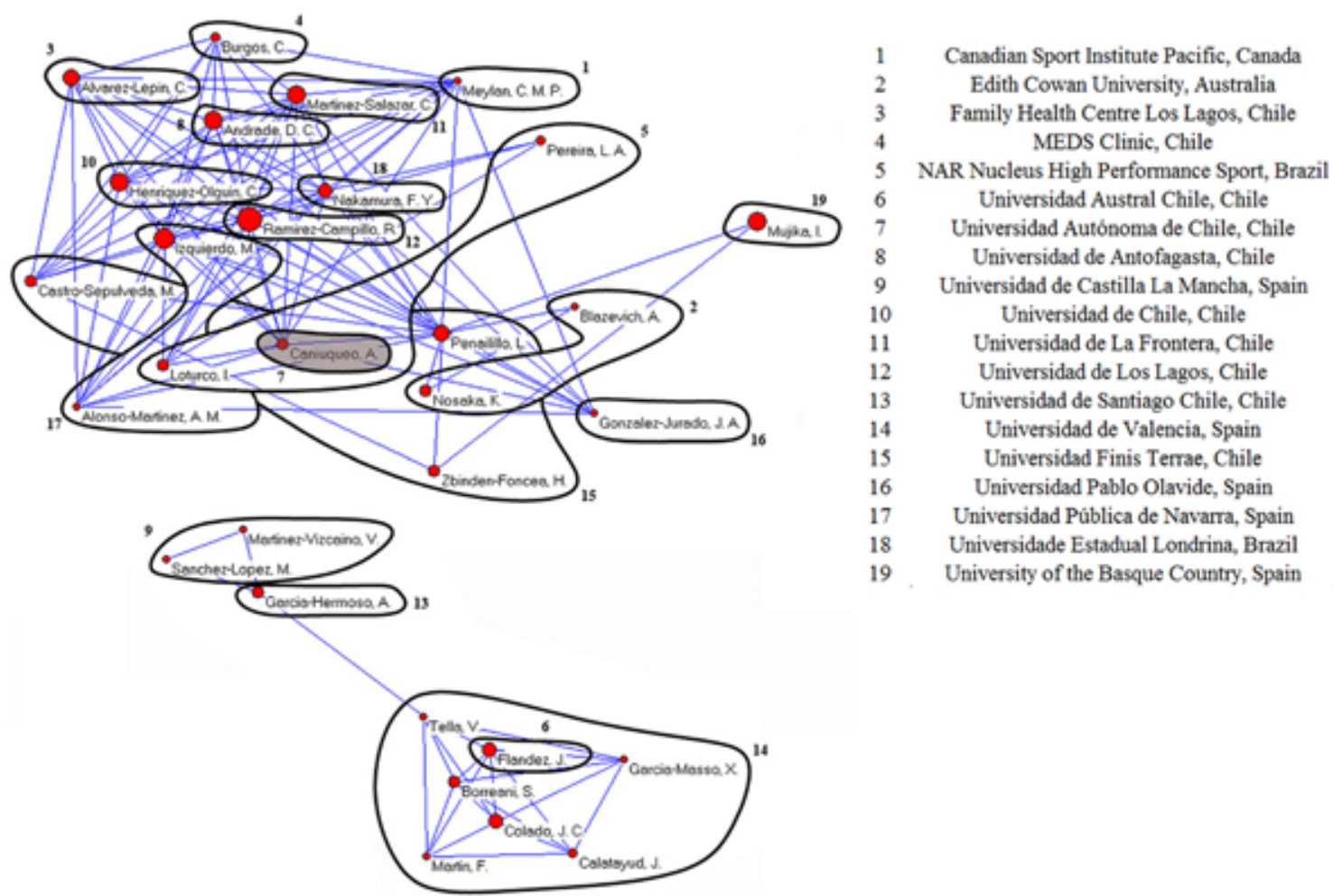

Source: prepared by authors. 
Finally, a cluster of 53 different journals has disseminated the selected Chilean Sport Sciences documents. As shown in Table 5, twelve journals have published five or more articles collecting 92 articles, representing $60.53 \%$ of total production. The Journal of Strength and Conditioning Research published 16 articles while Movimento included 11 publications. On the other hand, 29 journals have only published one article. Regarding the citation scores of these journals, there is no direct relationship between TLCS and TGCS, although the Journal of Strength and
Conditioning Research, European Journal of Applied Physiology and Medicine and Science in Sports and Exercise have exhibited the highest scores in both. The Journal of Strength and Conditioning Research was the most cited journal within the Web of Science collection (155), while the European Journal of Applied Physiology achieved the highest citation score within the articles included in the collection (5). Some journals, such as the Journal of Sports Science and Medicine or Journal of Sports Sciences, have scored in TGCS but no in TLCS.

Table 5 - Source journals for the articles and citations.

\begin{tabular}{|c|c|c|c|c|}
\hline ISSN & Journal & Articles & TLCS & TGCS \\
\hline $1064-8011$ & Journal of Strength and Conditioning Research & 16 & 3 & 155 \\
\hline 0104-754X & Movimento & 11 & 0 & 3 \\
\hline $1577-0354$ & Revista Internacional de Medicina y Ciencias de la Actividad Física y del Deporte & 9 & 0 & 4 \\
\hline $1600-0838$ & Scandinavian Journal of Medicine \& Science in Sports & 8 & 2 & 45 \\
\hline $1474-8185$ & International Journal of Performance Analysis in Sport & 7 & 1 & 14 \\
\hline $1303-2968$ & Journal of Sports Science and Medicine & 7 & 0 & 36 \\
\hline $1132-239 X$ & Revista de Psicología del Deporte & 7 & 0 & 7 \\
\hline $1439-6319$ & European Journal of Applied Physiology & 6 & 5 & 64 \\
\hline 0195-9131 & Medicine and Science in Sports and Exercise & 6 & 3 & 68 \\
\hline $0172-4622$ & International Journal of Sports Medicine & 5 & 0 & 13 \\
\hline 0264-0414 & Journal of Sports Sciences & 5 & 0 & 18 \\
\hline $1517-8692$ & Revista Brasileira de Medicina do Esporte & 5 & 1 & 1 \\
\hline- & 2 journals with 4 articles & 8 & - & - \\
\hline- & 3 journals with 3 articles & 9 & - & - \\
\hline- & 7 journals with 2 articles & 14 & - & - \\
\hline- & 29 journals with 1 article & 29 & - & - \\
\hline
\end{tabular}

TLCS - Total Local Citation Score $=$ Total citations in the collection to the journal. TGCS - Total Global Citation Score $=$ Total citations in WoS to papers in the journal in the collection. (Note that this is not necessarily the total citations to the journal in WoS; only to those papers in the journal included in the collection).

Source: prepared by authors.

\section{Discussion}

The present study has shown the existence of 152 documents related to Chilean Sport Sciences scientific production published in the Web of Science Core Collection indexes from 1981 to 2016. After the indexation of the first Chilean Sport Sciences article in the Web of Science in 1981, there was an approximately 30 -years period with a scarce scientific output. Then, up to 132 documents were published from 2013 onwards, drawing a progressive rise, and being Life Sciences the most represented research area. These results show the evolution of Chilean Sport Sciences scientific output, the orientation of Chilean Sport Sciences higher education and research institutions and the specialization and/or research focus of scholars in this country.
These results differ from those obtained by Andrade, López, Ramírez-Campillo, Beltrán, Rodríguez ${ }^{13}$ despite a similar methodology was used and after considering the time span was 4 years longer in the present study. These authors studied the South American research output indexed in the Web of Science from 1970 to 2012, focusing on the analysis of the amount of articles, scholars, subjects, institutions, impact factor, citations and journals involved, including data from Chile and depicted a different amount and distribution along time of the Chilean Sport Sciences articles indexed in the Web of Science. For example, they found four and 11 documents in 1978-1982 and 1998-2002 periods respectively while the present study only reported one document published in each period, that is, 1981 and 1999. The constant update of journals, and consequently of articles, indexed in the 
Web of Science may explain this situation. However, Andrade, López, Ramírez-Campillo, Beltrán, Rodríguez ${ }^{13}$ depicted a similar development of Chilean Sport Sciences with a rise from 1998 onwards and particularly during the 2008-2012 period. They also discovered the orientation of Sport Sciences scientific production to Life Sciences, being Physiology (44\% of total articles) the most-studied topic in the Sport Sciences within South American countries. In the same way, Pérez-Gutiérrez, Lagos-Hernández, Izquierdo-Macón ${ }^{16}$ carried out a bibliometric analysis of Sport Sciences scientific production published in Chile from 1912 to 2014, determining the distribution of articles, authors, institutions and countries per decade, the distribution of articles per decade, subject, research area and journal and the collaboration patterns. They found Physiology as the second most important subject $(16.18 \%)$ while in the present study it achieved 36 publications (23.68\% of total articles), confirming the orientation of Chilean Sport Sciences scholars to Life Sciences. As they stated, the focus of scholars on subjects associated to Life Sciences, such as Physiology or Sports Medicine, was triggered to the biological approach fostered in the physical education institutions from 1930s onwards or the establishment of the Chilean Society of Sports Medicine in $1955^{8,9,16,31}$.

Social Sciences collected 42 documents, $27.63 \%$ of total Sport Sciences production, becoming the second most represented research area and widening the orientation of Sport Sciences studies developed in Chile. The appearance of certain subjects during the last years, such as Biomechanics, Didactics, Mathematical Methods, Nutrition or Scientometrics, with three or more articles, also shows the growth of this field and its multidisciplinary character ${ }^{16,25,32,33}$, improving, widening and strengthening the knowledge about physical activity and sports from other approaches.

The analysis of the collaboration patterns presented a predominance of multi-authored articles. Pérez-Gutiérrez, Lagos-Hernández, Izquierdo-Macón ${ }^{16}$ study, regarding the Sport Sciences scientific output published in Chile from 1912 to 2014, showed single-authored articles predominated until the decade of 2010 and a mean of 1.54 authors per article. During the last period these authors analyzed (2010-2014), the amount of multi-authored articles increased significantly achieving 75\% of collaboration and mean of 2.96 authors per article. As collaboration has been defined as a key element to improve quality in scientific production, these results should be understood in two different but complementary ways. First, there has been a trend towards collaborative research within Sport Sciences in Chile from 2010 onwards, both in national- and internationalindexed production although single-authored papers dominated the scientific documents published in Chile for almost a century ${ }^{16}$. And second, Chilean Sport Sciences scholars have usually participated in collaborative networks for those papers indexed in the Web of Science since it indexes the top international and regional journals in the world and these journals publish most of the significant scholar results ${ }^{34}$. Thus, the Web of Science demands foster teamwork among Sport Sciences scholars affiliated to Chilean institutions for publishing their papers. The best research works or projects, generally developed by a group of scholars, are published in top journals.
Regarding the collaboration of the most productive authors, a group of 15 scholars published six or more articles, being Ramirez-Campillo the most prolific author and Caniuqueo the most collaborative. Brazilian and Spanish scholars were also included within this collaboration network. These results show the importance of teamwork for getting published in journals indexed in the Web of Science but also for developing research since the three most productive authors have collaborated with at least 113 scholars. In the same way, Caniuqueo signed six papers but he achieved the highest score in the collaboration index, illustrating the extent of his collaboration network. This should be understood as a way for improving the quality of his research.

In the Spanish context, Valenciano Valcárcel, Devís-Devís, Villamón, Peiró-Velert ${ }^{28}$ analyzed the collaboration among authors publishing in the 16 most important Sport Sciences journals published in Spain from 1999 to 2005. They discovered a mean of 2.50 authors per article in total and a group of 36 scholars publishing 10 or more articles with a mean of 3.89 authors per article. Despite the methodology, time span, context and results differences between both studies, it should be suggested collaboration benefits productivity and it is necessary for improving research quality.

The map of the collaboration patterns depicted two networks with 20 and 10 scholars respectively and representing 19 different institutions, including countries such as Australia, Brazil, Canada or Spain. Valenciano Valcárcel, Devís-Devís, Villamón, Peiró-Velert ${ }^{28}$ also found a $16.39 \%$ of foreign authors, most of them from Brazil, Portugal and Argentina, participating in the $12.77 \%$ of total articles. Therefore, international collaboration is a widespread and frequent practice in Sport Sciences in Chile, corroborating previous results that showed the intensification of international collaboration in the last decade worldwide ${ }^{6}$. Thus, Switzerland and Ireland obtained the highest values regarding international collaboration, $70.3 \%$ and $67.4 \%$ respectively, in 2010-2011 period while Brazil, the only South American country included in the study, achieved a $40.7 \% \%^{6}$. In the case of the first network (Figure 1), most of the authors are collaborating among them although some scholars have participated to a lesser extent. This network should be highlighted due to the amount of institutions and the diversity of countries working together as well as the great number of interactions among authors. In the case of the second network, two clusters of Chilean and Spanish universities are shown, emphasizing the participation of four different institutions and the non-existence of relationship between scholars of the same country.

And regarding the dissemination of the Chilean Sport Sciences scientific output, 12 journals, mainly dedicated to Life Sciences, collected the $60.53 \%$ of total production. The Journal of Strength and Conditioning Research and the European Journal of Applied Physiology achieved the highest TGCS and TLCS, respectively. Similar results were obtained by Andrade, López, Ramírez-Campillo, Beltrán, Rodríguez ${ }^{13}$ when analyzing South American Sport Sciences scientific output. Four of the 19 most recurrent analyzed journals were only multi-disciplinary while the rest were oriented to Life-Sciences, particularly to Medicine and Physiology. However, Pérez-Gutiérrez and 
Lagos-Hernández ${ }^{15}$ prepared a bibliography of Sport Sciences journals published in Chile from 1929 to 2014, presenting their bibliographic and bibliometric characteristics and assessing their quality. These authors discovered 12 journals, all of them with a multidisciplinary approach with the exception of Archivos de la Sociedad Chilena de Medicina del Deporte [Archives of the Chilean Society of Sports Medicine]. And the same situation was evidenced in the Spanish journals dedicated to Sport Sciences, being the majority multi-disciplinary although some of them were specialized in subjects such as Medicine, Didactics and Psychology ${ }^{33}$. Therefore, the analysis of national contexts shows the existence and relevance of multi-disciplinary journals for the dissemination of Sport Sciences scientific production within a country ${ }^{15,33}$, while the analysis of the literature indexed in international databases, such as the Web of Science, presents the predominance of Life-Sciences oriented journals for publishing Sport Sciences papers, probably as a consequence of the scholars' interest and specialization ${ }^{13}$.

Finally, the use of the Web of Science as the only source of information for data mining and the inclusion of article and review type of documents are the main limitations of the present study. In this way, future studies should analyze the Chilean Sport Sciences scientific output indexed in other international databases such as Scopus or Pubmed, the amount and characteristics of funded research projects of Chilean Sport Sciences scholars for complementing the present results, the development of Sport Sciences production in other South American countries for comparing results as well as periodically follow the development of this field of knowledge.

\section{Conclusions}

A total of 152 Sport Sciences documents affiliated to Chilean institutions have been published from 1981 to 2016 in the Web of Science Core Collection indexes (SCI-EXPANDED, SSCI and A\&HCI), with a significant rise from 2013 onwards and mainly dedicated to Life Sciences, particularly to Physiology and Sports Training Theory. Social Sciences and Technology research areas were also represented but to a lesser extent. Scholars have collaborated for developing Sport Sciences research, with a mean of 5.26 authors per article, including the participation of foreign authors from Australia, Brazil, Canada or Spain. Ramirez Campillo was the most important scholar regarding the number of papers, signatures and amount of collaborators while Caniuqueo achieved the highest collaboration index. Two networks were discovered, depicting different patterns of collaboration. In the first one, collaboration was established among most of the scholars including almost as many institutions as authors, while the second one involved four different institutions from Chile and Spain but there was no relationship between scholars of the same country. Finally, $60.53 \%$ of total Chilean Sport Sciences production has been disseminated in 12 journals, most of them Life Sciences-oriented.

In summary, Chilean Sport Sciences scientific production indexed in the Web of Science shows the progressive development and strengthening of this field of knowledge, clearly oriented to
Life Sciences, teamwork and international collaboration. Also, it should be highlighted the establishment of an important network including scholars from Australia, Brazil, Canada, Chile and Spain which is propelling Sport Sciences research in this country. This study complements the results of the previous works developed at the national level in Chile, allowing comparison between them and providing a deeper viewpoint of the Sport Sciences scientific production history and development in this country. Data provided could be considered by academics, institutions and/or policymakers for making decisions in relation to the strengthening of the research areas and subjects less represented as well as the communication and collaboration patterns within Sport Sciences.

\section{References}

1. Comisión Nacional de Investigación Científica y Tecnológica. Historia 2017. Available from: http://www.conicyt.cl/sobreconicyt/historia/ [Accessed 18th December 2017].

2. Comisión Nacional de Investigación Científica y Tecnológica. ¿Qué es FONDECYT? 2017. Available from: http://www.conicyt.cl/fondecyt/sobre-fondecyt/que-es-fondecyt/ [Accessed 18th December 2017].

3. Larsen PO, von Ins M. The rate of growth in scientific publication and the decline in coverage provided by Science Citation Index. Scientometrics. 2010;84(3):575-603.

4. Price DJdS. Little Science, Big Science... and Beyond. New York: Columbia University Press; 1986.

5. Thomson Reuters. Using bibliometrics: A guide to evaluating research performance with citation data 2008. Available from: http://ips.clarivate.com/m/pdfs/325133_thomson.pdf [Accessed 12th Novemeber 2014].

6. Moya-Anegón Fd. Principales indicadores cienciométricos de la actividad científica chilena 2013. Informe 2015. Santiago - Madrid - Viña del Mar: Altazor Ediciones; 2015.

7. Cofré Iluffi M. El DEFDER y sus 80 años: el Instituto Superior de Educación Física y Técnica, hoy Departamento de Educación Física, Deportes y Recreación. Educación Física-Chile. 1986;LVII(208):12-5.

8. Cofré Iluffi M. El Instituto de Educación Física y Manual: ocho décadas. Educación Física-Chile. 1989;LXI(219):9-19.

9. Guarda Etcheverry S. Historia del Instituto de Educación Física. Educación física Chile. 2006 (265):13-24.

10. Pérez-Gutiérrez M, Gutiérrez-García C. Historia de la revista Educación Física-Chile: aproximación bibliométrica (1929-2013). Movimento. 2015;21(3):603-16.

11. Consejo Nacional de Educación. Elige carrera 2017. Available from: http://www.eligecarrera.cl/aspx/index.aspx [Accessed 20th September 2017].

12. Ministerio de Educación. Buscador de instituciones 2017. Available from: http://www.mifuturo.cl/index.php/donde-y-queestudiar/buscador-de-instituciones [Accessed 20th September 2017].

13. Andrade DC, López BA, Ramírez-Campillo R, Beltrán AR, Rodríguez RP. Bibliometric analysis of South American research in sports science from 1970 to 2012. Motriz: J. Phys. Ed. 2013;19(4):783-91. 
14. Ministerio de Educación. Buscador de carreras 2017. Available from: http://www.mifuturo.cl/index.php/donde-y-que-estudiar/ buscador-de-carreras [Accessed 20th September 2017].

15. Pérez-Gutiérrez M, Lagos-Hernández RI. Sport Sciences scientific journals in Chile (1929-2014): bibliography, characteristics, quality. Motriz: J. Phys. Ed. 2015;21(4):442-51.

16. Pérez-Gutiérrez M, Lagos-Hernández RI, Izquierdo-Macón E. Sport Sciences' scientific production published in Chile (19122014): a bibliometric approach. Movimento. 2016;22(4):1121-36.

17. Collier S, Sater WF. Historia de Chile, 1808-1994. Madrid: Cambridge University Press; 1999.

18. Silva Galdames O. Breve historia contemporánea de Chile. México D.F.: Fondo de Cultura Económica; 1995.

19. Garretón MA, Martínez J. Universidades chilenas: historia, reforma e intervención. Santiago: SUR; 1985.

20. Consejo Académico Nacional de Educación Física. Universidades del Consejo 2017. Available from: https://www.canef.cl/consejo [Accessed 20th September 2017].

21. Universia Chile. Buscador 2017. Available from: http://www. universia.cl/estudios/busqueda-avanzada/magisters/pedagogia/ $\mathrm{dg} / 166 / \mathrm{ka} / 649$ [Accessed 20th September 2017].

22. Pérez-Gutiérrez M, Lagos-Hernández RI. Análisis bibliométrico de los artículos publicados en la revista del Instituto Nacional de Deportes: 2004-2014. Rev. cienc. act. fís. Inst. Nac. Deportes. 2015;10 7-18.

23. Rubilar Bernal CA, Pérez-Gutiérrez M. Análisis bibliométrico de los artículos científicos de las Ciencias de la Actividad Física y del Deporte publicados en Chile durante el gobierno militar (1973-1990). Rev. Bras. Ciênc. Esporte. In press.

24. Thomson Reuters. Web of Science 8.0 Workshop: Science Citation Index Expanded, Social Sciences Citation Index, Arts \& Humanities Citation Index. Available from: http://www.google. es/url? sa $=$ t\&rct $=\mathrm{j} \& \mathrm{q}=\&$ esrc $=\mathrm{s} \&$ source $=$ web $\& \mathrm{~cd}=1 \& \mathrm{ved}=0 \mathrm{C}$ DcQFjAA\&url=http\%3A\%2F\%2Fip-science.thomsonreuters. com $\% 2$ Fm\%2Fpdfs $\% 2$ Fmgr\%2Fws-wos-8-0-0807.pdf\&ei=rII8 U9yWD6P00gH6zYGIBQ\&usg=AFQjCNFX1MLYmsq61O6Fy rkoNm6ef9ZJnw\&bvm=bv.63934634,d.cWc\&cad=rja [Accessed 20th September 2017].

25. Devís-Devís J, Valenciano Valcárcel J, Villamón M, PérezSamaniego V. Disciplinas y temas de estudio en las ciencias de la actividad física y el deporte. Revista Internacional de Medicina y Ciencias de la Actividad Física y del Deporte. 2010;10(37):150-66.

26. Thomson Reuters. Web of Science Core Collection Help. Research Areas (Categories / Classification) 2017. Available from: https://
images.webofknowledge.com/images/help/WOS/hp_research_areas_easca.html [Accessed 19th July 2017]

27. López López P. Introducción a la bibliometría. Valencia: Promolibro; 1996.

28. Valenciano Valcárcel J, Devís-Devís J, Villamón M, Peiró-Velert C. La colaboración científica en el campo de las Ciencias de la Actividad Física y el Deporte en España. Rev Esp Doc Cient. 2010;33(1):90-105.

29. Peset F, Ferrer-Sapena A, Villamón M, González LM, TocaHerrera JL, Aleixandre-Benavent R. Scientific literature analysis of Judo in Web of Science. Archives of Budo. 2013;9(2):81-91.

30. Pérez-Gutiérrez M, Valdés-Badilla P, Gutiérrez-García C, Herrera-Valenzuela T. Taekwondo scientific production published in the Web of Science (1988-2016): collaboration and topics. Movimento. In press.

31. Bisquertt Susarte L. El Instituto de Educación Física y Técnica en su medio siglo. Revista Chilena de Educación Física. 1957;XXII(91-92):3-26.

32. Vicente Pedraz M. Definición del objeto de estudio en las Ciencias de la Actividad Física. A Coruña, Congreso Galego de Educación Física; 1998. p. 73-5.

33. Valenciano Valcárcel J, Devís Devís J, Beltrán Carrillo VJ. La investigación y las revistas científicas de la actividad física y el deporte en España. Fuentes: Revista de la Facultad de Ciencias de la Educación. 2008 (8):209-18.

34. Testa J. The Web of Science journal selection process 2016. Available from: http://wokinfo.com/essays/journal-selectionprocess/ [Accessed 14th September 2017].

\section{*Corresponding author}

Mikel Pérez-Gutiérrez

Department of Education, University of Cantabria. Avda. de Los Castros $s / n$, 39005, Santander, Cantabria, Spain

Email: mikel.perez@unican.es

Manuscript received on October 24, 2017

Manuscript accepted on January 17, 2018

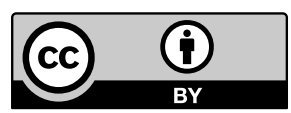

Motriz. The Journal of Physical Education. UNESP. Rio Claro, SP, Brazil - eISSN: 1980-6574 - under a license Creative Commons - Version 4.0 